\title{
Local catastrophe caused by tephra input near Přemyslovice (Moravia, Czech Republic) during the Middle Miocene
}

\author{
Kamil ZÁGORŠEK, Slavomír NEHYBA, Pavla TOMANOVÁ PETROVÁ, Šárka HLADILOVÁ, \\ Maria Aleksandra BITNER, Nela DOLÁKOVÁ, Juraj HRABOVSKÝ and Vladimíra JAŠKOVÁ
}

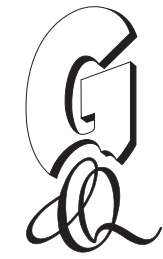

\begin{abstract}
Zágoršek K., Nehyba S., Tomanová Petrová P., Hladilová Š., Bitner M. A., Doláková N., Hrabovský J. and Jašková V. (2012) - Local catastrophe caused by tephra input near Přemyslovice (Moravia, Czech Republic) during the Middle Miocene. Geol. Quart., 56 (2): 269-284, doi: 10.7306/gq.1021

Colonization by marine organisms such as foraminifers, molluscs, bryozoans, brachiopods and red algae during the Middle Miocene (Early Badenian) transgression near Přemyslovice (Carpathian Foredeep) was initially affected by a cool water current of unclear origin. However, shortly afterwards, fallout of volcanic material caused a total termination of the biota. After this catastrophe, the biota started recolonize the area. The succeeding association, adopted to warm-water input, is characteristic of the climatic optimum during the Early Badenian and is comparable with those of other sections referred to this interval in the Carpathian Foredeep (such as Kralice nad Oslavou, Podbřežice, and Hluchov).
\end{abstract}

Kamil Zágoršek, Department of Palaeontology, National Museum, Václavské náměstí 68, CZ-115 74 Prague, e-mail: kamil.zagorsek@nm.cz; Slavomír Nehyba, Nela Doláková and Juraj Hrabovský, Institute of Geological Sciences, Masaryk University, Kotlářská 2, 61137 Brno, Czech Republic; Pavla Tomanová Petrová, Czech Geological Survey, Leitnerova 22, 65869 Brno, Czech Republic; Š́rka Hladilová, Department of Biology, Faculty of Education, Palacký University, Purkrabská 2, 77146 Olomouc, Czech Republic: Maria Aleksandra Bitner, Institute of Paleobiology, Polish Academy of Sciences, Twarda 51/55, 00-818 Warszawa, Poland; Vladimíra Jašková, Muzeum Prostějovska v Prostějově, náměstí T. G. Masaryka 2, 79601 Prostějov, Czech Republic (received: May 11, 2011; accepted: February 3, 2012; first published online: May 28, 2012).

Key words: Middle Miocene, Carpathian Foredeep, Moravia, Czech Republic, tephra fallout, succession of biota.

\section{INTRODUCTION}

Sediment supply has long been recognized as a key factor in the creation and destruction of accommodation space and thus in sequence stratigraphy (Catuneanu, 2006). The input of clastic material also affects the quality and quantity of biota by affecting ecological conditions. Sudden increases in clastic input can have a serious affect on the biota. Volcanic processes are known for "sudden" inputs of large amount of clastic/volcaniclastic material into depositional environments (Fisher and Schmincke, 1984). Tephra beds are also recorded in the Neogene deposits of the Carpathian Foredeep especially in the Early Badenian when fallout tephra form basin-wide deposits typically several centimetres thick and exceptionally reaching several metres (Nehyba, 1997). These tephra beds are of use in correlation (Nehyba and Roetzel, 1999; Nehyba and Stráník, 2005), but their potential effect on ecological conditions has not yet evaluated. Boreholes through this interval near
Přemyslovice (Moravia, Czech Republic) have provided us such a possibility. Detailed analysis of the reaction of various planktonic and benthic biotas to intense tephra input into the depositional environment is the main topic of this paper.

\section{GEOLOGICAL SETTING}

The Neogene deposits studied are a part of the Carpathian Foredeep (CF). The CF is a peripheral foreland basin that developed from subsurface loading of the Alpine-Carpathian orogenic belt on the passive margin of the Bohemian Massif (Picha et al., 2006). Deposition began in Egerian-early Eggenburgian times and continued in the area of the Czech Republic up to the Late Badenian (Brzobohatý and Cicha, 1993). During the early Middle Miocene the CF geometry was re-organized, because the NNW- and NW-oriented compression of the Carpathian orogenic wedge changed towards NNE- and NE-oriented compression. The maximum thickness of the 


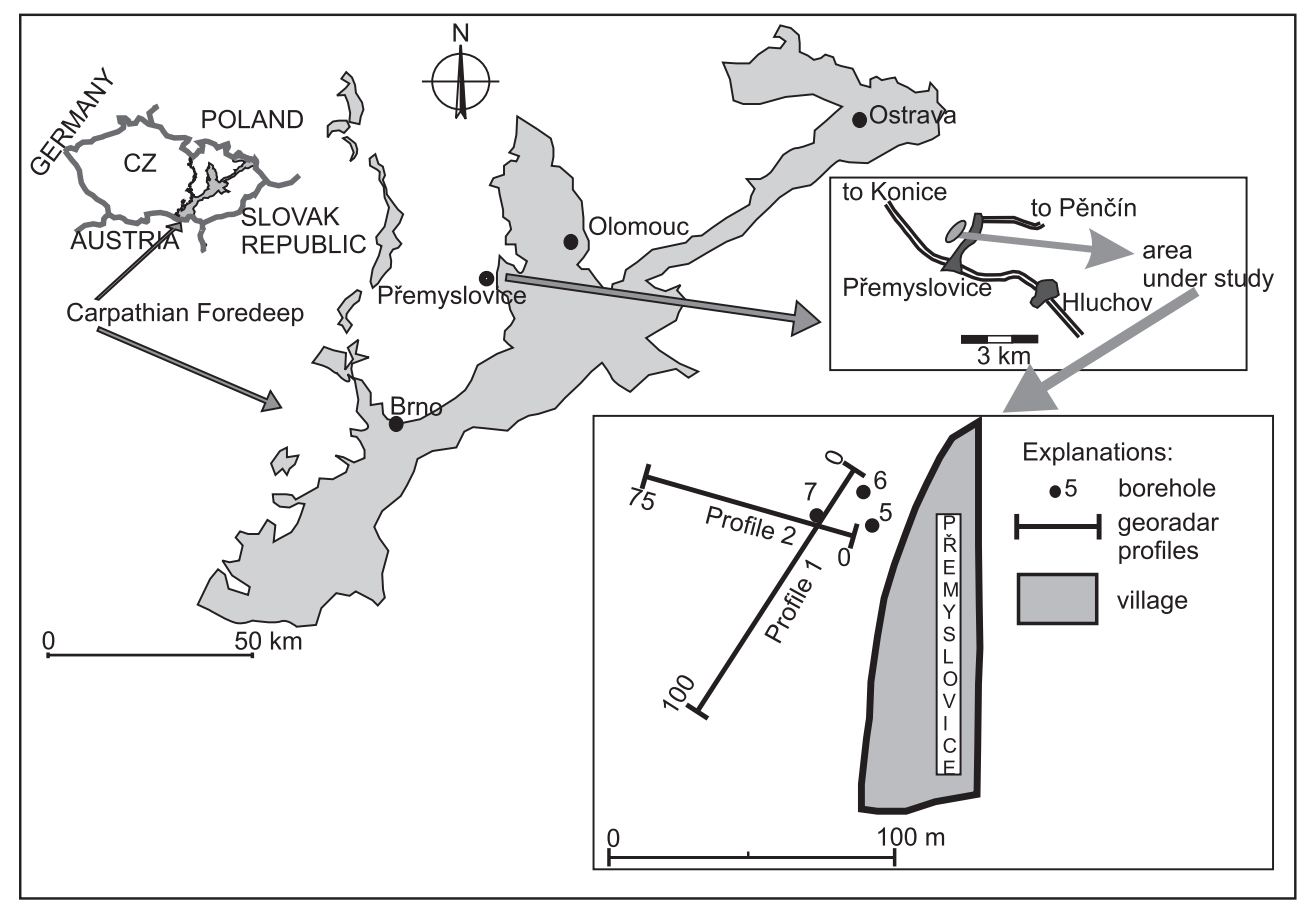

Fig. 1. Geographical sketch of the position of the boreholes studied

Lower Badenian deposits is more than $700 \mathrm{~m}$. Deposits of coarse-grained Gilbert deltas, coastal and lagoonal deposits and deeper-marine deposits have all been recognized (Nehyba, 2000). The deeper-marine deposits ("Tegel") comprise mudstones with silts, clays and shell debris and predominate in the infill of the basin. They have been interpreted as outer shelf deposits or hemipelagites (Nehyba et al., 2008). Coastal, lagoonal deposits as well as occurrences of algal and bryozoan limestones, calcareous sandstones and beds of distal airfall tephra (Nehyba, 1997; Dolakova et al., 2008) are restricted both areally and in thickness. Isolated relics of Lower Badenian deposits can be found far to the west of the present extent of the basin (Nehyba and Hladilová, 2004). Such varied Neogene deposits have been recognized also in central Moravia, around Prostějov (Fig. 1).

The Miocene deposits of the northwestern part of the CF near the village of Prremyslovice were studied for the first time by Schwarz (1946). A new investigation was initiated by Jašková (1998) after finding rich bryozoan-bearing deposits in the vicinity of Přemyslovice. Because no sections were available close to these locations, we decided to drill shallow boreholes to examine the sedimentary succession. Preliminary boreholes were drilled in 2006 (Zágoršek and Holcová, 2009).

Regionally, Precambrian crystalline basement is covered by lower Carboniferous (Culmian) clastic deposits of the Drahany Highland unit (Mísař et al., 1985). Deposits of the Rozstání Fm. (Visean), composed of alternating fine-grained greywackes, siltstones and shales, form the pre-Neogene substrate around Přmyslovice (Otava et al., 1995). NW-SE oriented faults (the Haná fault belt), which were active during the Variscan orogeny and were reactivated during the Alpine orogeny, played an important role in the creation of depositional space during the Neogene. A complicated relief of fault-bounded steep, narrow depressions and intrabasinal highs was formed, dipping at a high angle towards the central part of the basin (Zapletal, 2004). The oldest Neogene marine deposits are Karpatian in age (Vysloužil, 1981; Bubík and Dvořák, 1996). A dominant role in the Neogene sedimentary succession is played by the Lower Badenian deposits (Fig. 2), which often directly overlie the pre-Neogene substrate. They reach their greatest thickness (more than $100 \mathrm{~m}$ ) in the Prostějov and Lutín depressions. Numerous isolated relics of Neogene deposits in the Drahany Highland represent prolongation of the Prostějov depression towards the NW (Kalabis, 1961; Novák, 1975; Jašková, 1998; Zapletal et al., 2001; Zapletal, 2004). These deposits, up to a few metres thick, are usually formed red algal limestones and sands whereas conglomerates and clays are rare.

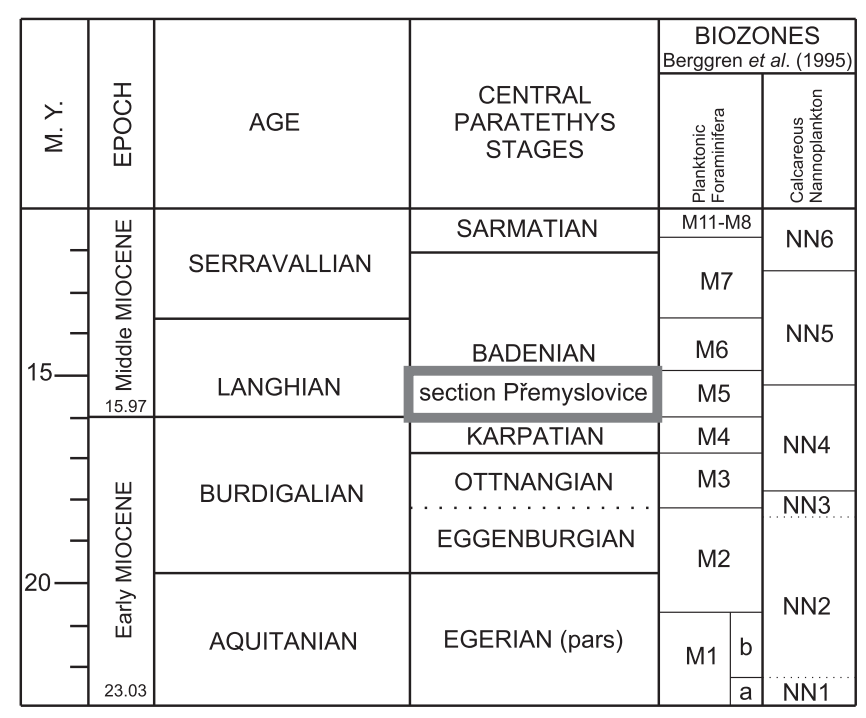

Fig. 2. Stratigraphic position of the section studied 


\section{METHODS}

Recently, three new shallow boreholes, PY5-7, have been drilled near Přemyslovice (GPS location 49³4.169’ N and 016 57.928'E) called PY5 to PY7 (Fig. 1). Here, we provide detailed analysis of the borehole logs.

Combined sieving and laser methods were used for grain-size analysis. The Retch AS 200 sieving machine analysed the coarser grain fraction (4-0.063 mm, wet sieving), a Cilas 1064 laser diffraction granulometer being used for the finer fractions $(0.0004-0.5 \mathrm{~mm})$. Ultrasonic dispersion, distilled water and washing in sodium polyphosphate were used prior to analyses in order to avoid flocculation of the particles analysed. The average grain size is demonstrated by the graphic mean (Mz) and the uniformity of the grain-size distribution/sorting via the standard deviation $(\sigma \mathrm{I})$ (Folk and Ward, 1957). Lithofacies analysis was done following Tucker (1988), Walker and James (1992) and Nemec (2005). The shape and roundness of the coarsest grain fraction ( $>4 \mathrm{~mm}$ - sieve separation) were estimated visually using the method of Powers (1982). Heavy minerals were studied in the grain-size fraction $0.063-0.125 \mathrm{~mm}$. The mineral compositions of selected heavy minerals were determined using the Cameca SX 100 electron microprobe at the Joint Laboratory of Electron Microscopy and Microanalyses of the Masaryk University and the Czech Geological Survey, Brno.

Ground penetrating radar (GPR) scanning employed a Pulse Ekko Pro radar, manufactured by the Canadian company Sensor \& Software, at a frequency of $50 \mathrm{MHz}$ with an antenna distance of $3 \mathrm{~m}$. The measurement interval was $0.5 \mathrm{~m}$. The Acme Analytical Laboratories Ltd. (Vancouver) produced chemical analyses of selected samples by standard analytical methods.

Sediments were soaked in warm water with sodium carbonate for one day for dissaggregation, and then washed under running water through $0.063 \mathrm{~mm}$ mesh sieves. Foraminifers were picked from the fraction, and identified with a WILD binocular microscope.

Groups of agglutinated foraminifers, deep- and shallow-water foraminifers and euryoxybiont foraminifers were interpreted according to the palaeoecological studies of Kaiho (1994), Spezzaferri and Ćorić (2001), Spezzaferri et al. (2004) and Murray (2006). Biostratigraphic data were correlated with planktonic foraminiferal zones by Berggren et al. (1995). Recognition of central Paratethys regional stages and the biostratigraphic evaluation of planktonic foraminifers followed Cicha et al. (1998).

The bryozoans were studied from the fraction larger than $200 \mu \mathrm{m}$. A few samples from more lithified rock samples were "laboratory weathered" and/or treated with acetic acid as described by Zágoršek and Vávra (2000). Finally the samples were cleaned in an ultrasonic bath. The detailed determination and analyses of skeleton preservation were carried out with a scanning electron microscope (SEM; JSM-6400 Jeol) in the Palaeontological Department of Vienna University and a Hitachi S3700N in the Paleontological Department of National Museum Prague.
Altogether fifteen samples of three taxa (Smittina cervicornis, Exidmonea sp. and celleporids) were selected for geochemical studies. The samples selected came from the same depth (borehole PY7 depth $2.3 \mathrm{~m}$ - just above the tephra layers). More than $50 \mathrm{mg}$ of skeletal material was required for geochemical analysis. The bryozoan skeletons were manually separated from the enclosing rocks, cleaned in an ultrasonic cleaner and pulverized. Cathodoluminescence was used to evaluate possible diagenetic alteration. The analyses of stable isotopes were performed by the Laboratory of the Czech Geological Survey, Prague. Oxygen and carbon isotope measurements were performed on a Finnigan MAT-251. The carbon and oxygen isotopic ratios are expressed in $\delta$ notation.

The molluscs were studied from washed samples (PY5 - 11 samples, PY6 - 14 samples, PY7 - 16 samples).

Altogether twelve samples were used for palynological studies. They were treated with cold $\mathrm{HCl}(35 \%)$ and $\mathrm{HF}(70 \%)$, removing carbonates and silica. Separation of the palynomorphs from the rest of the residue was carried out using $\mathrm{ZnCl}_{2}\left(\right.$ density $\left.=2 \mathrm{~g} / \mathrm{cm}^{3}\right)$.

\section{RESULTS}

\section{GEOPHYSICS}

Two georadar profiles were measured at the locality. The position of the profiles is shown in Figure 1. Determination of the relief of the underlying pre-Neogene bedrock and the shape of the body of the Early Badenian deposits were the main objectives of this survey.

Interpretation of the geophysical profiles is shown in Figure 3. The profiles indicate that the Early Badenian deposits rest on a highly irregular and inclined relief. The thickness of Neogene deposits is only few metres and is controlled by the relief morphology, with greater thicknesses in depressions and thinning up slope. Neogene deposits rest here on weathered Culm sedimentary rocks. The thickness of the package of weathered substrate rocks is approx. 4-6 m. The basement relief is affected by tectonic structures/dislocations.

\section{FACIES ANALYSIS}

Sedimentary facies are considered to be the basic "building blocks" of the sedimentary succession (Harms et al., 1975; Walker and James, 1992; Reading, 1996). Lithofacies here are defined according to their petrography, grain size and preserved sedimentary structures. Lithofacies descriptions are shown in Table 1 and their occurrence in lithostratigraphic logs (Fig. 4).

Lithofacies have been combined, based on their spatial grouping and depositional architecture, with the palaeontological content of the beds. Such an approach has led to the recognition of four depositional units $(\mathrm{A}-\mathrm{D})$ within the sedimentary succession studied. The occurrences of the units can be followed in Figure 4. The units represent the basis for an interpretation of the various modes of sedimention (see description of the units later in the text). 

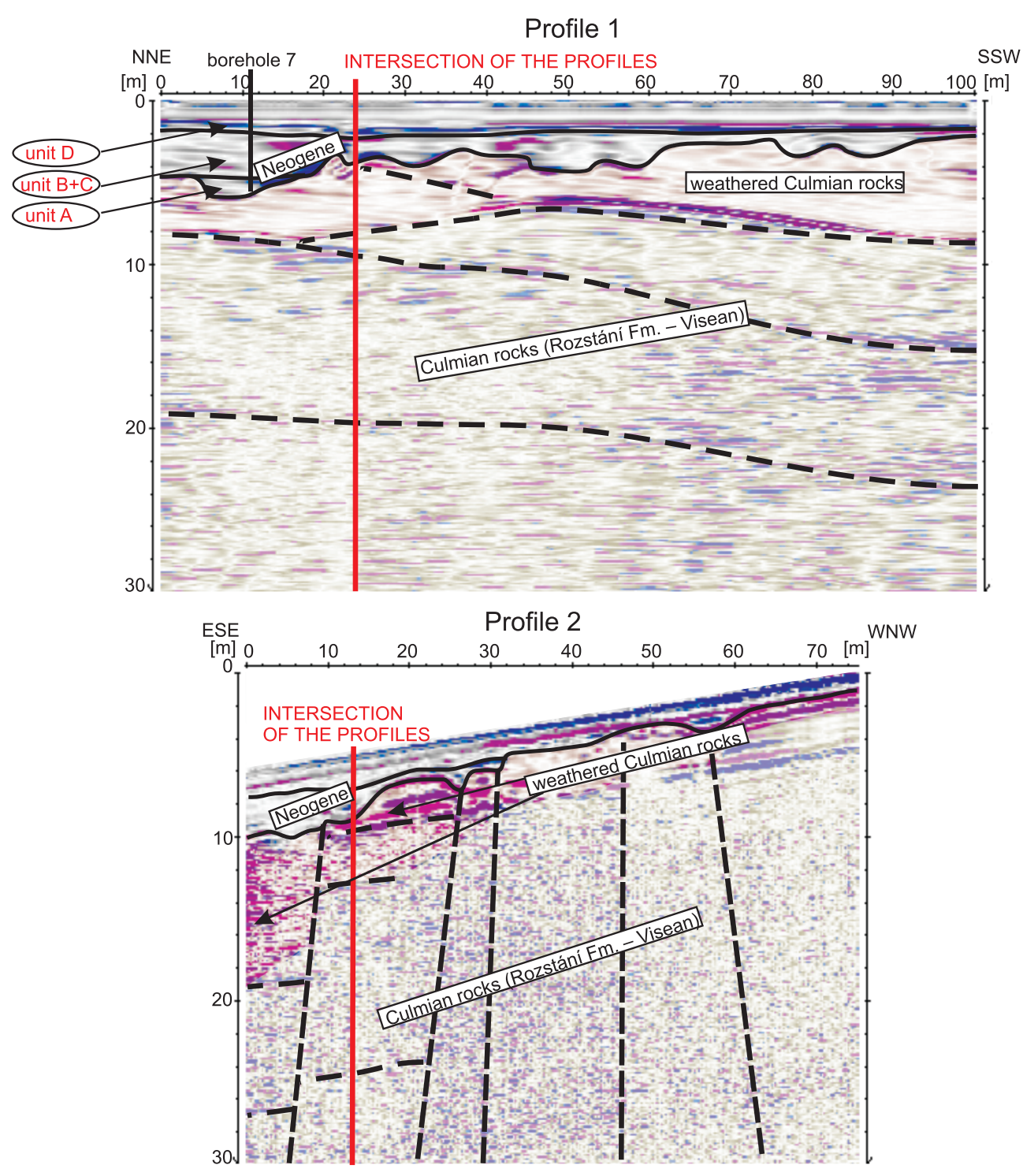

Fig. 3. Interpretation of georadar profiles at the Přemyslovice locality

List of lithofacies recognized in the studied Neogene deposits of Přemyslovice

\begin{tabular}{|c|c|}
\hline Sl & Light green irregularly laminated fine sand $(\mathrm{Mz}=4.6-5.6 \phi, \sigma \mathrm{I}=2.3-2.9 \phi)$. \\
\hline Sf & $\begin{array}{l}\text { Light grey-green fine sand, whitish mottled. Parallel lamination to flaser bedding. Laminae and thin layers of sandstones (up to } 3 \mathrm{~cm} \text { thick) } \\
\text { are separated by laminae of greyish mudstone. Shell debris and granules and small pebbles of Culmian rocks along sharp base (up to } 0.5 \mathrm{~cm} \text { ). } \\
\qquad \mathrm{Mz}=5.9 \phi, \sigma \mathrm{I}=2.9 \phi\end{array}$ \\
\hline $\mathrm{Mg}$ & Light grey-green mudstone - muddy gravel with angular clasts of Culmian rocks (up to $10 \mathrm{~cm}$ ). $\mathrm{Mz}=2.5 \phi, \sigma \mathrm{I}=4.3 \phi$ \\
\hline Mi & Light green to whitish green mudstone with angular intraclasts of green clay up to $2 \mathrm{~cm}$, chaotic fabric, distorted sandy laminae \\
\hline Ms & Light green to grey-green sandy mudstone \\
\hline $\mathrm{Hl}$ & Alternation of flaser beds of calcareous sand and calcareous clay - flaser-wavy bedding. Sharp base \\
\hline $\mathrm{Lg}$ & $\begin{array}{l}\text { Whitish calcareous sandstone to sandy limestone, sharp base, rare angular intraclasts of yellowish mudstone (up to } 1 \mathrm{~cm} \text { ), fossiliferous. } \\
\text { Angular clasts of Culmian rocks at the base (up to } 10 \mathrm{~cm} \text { ) }\end{array}$ \\
\hline V1 & Whitish very fine calcareous tephra, planar lamination. $\mathrm{Mz}=3.9-4.7 \phi, \sigma \mathrm{I}=1.8-2.4 \phi$ \\
\hline Vi & $\begin{array}{l}\text { Whitish grey to white calcareous tephra with admixture of angular intraclasts of grey-green to light grey mudstone (up to } 5 \mathrm{~cm} \text { ). } \\
\qquad \mathrm{Mz}=4.6-4.7 \phi, \sigma \mathrm{I}=1.9-2.1 \phi\end{array}$ \\
\hline
\end{tabular}


A

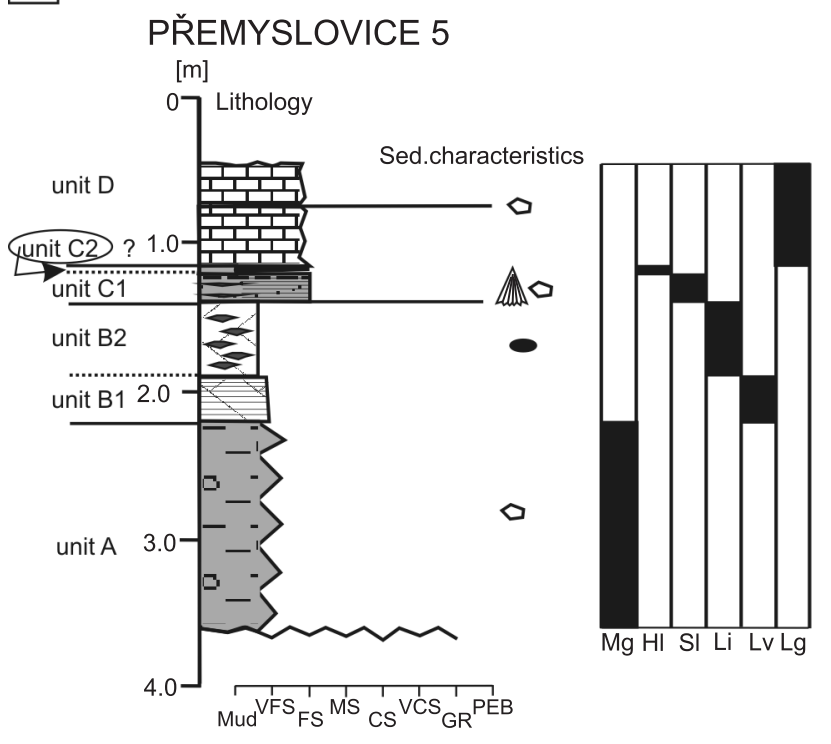

$B$

\section{PŘEMYSLOVICE 6}

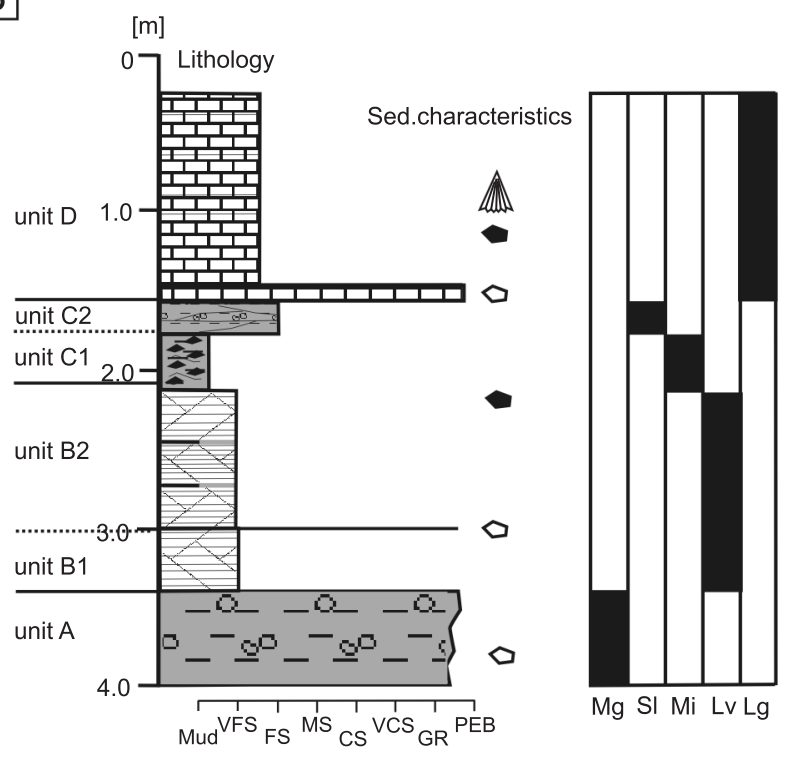

C

\section{PŘEMYSLOVICE 7}
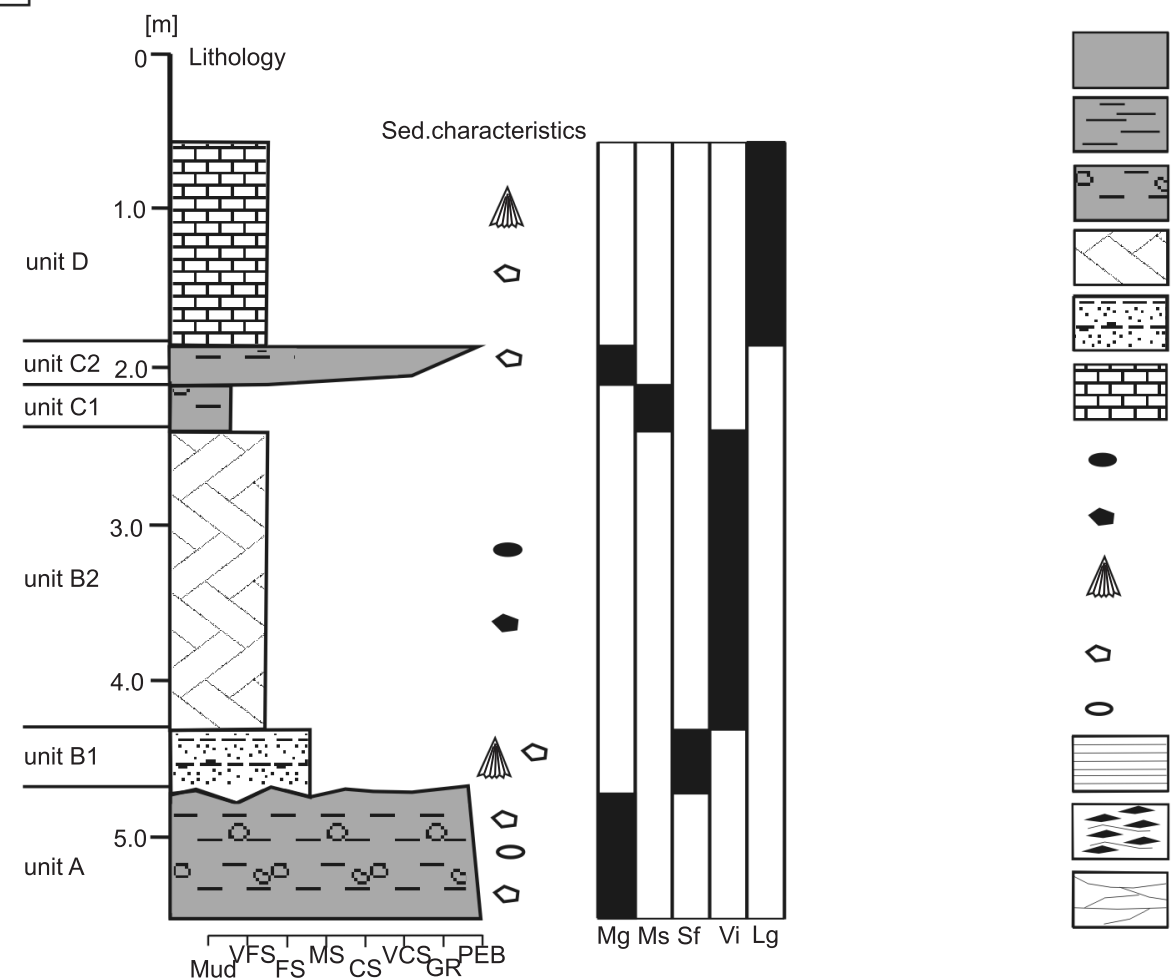

mudstone

sandy mudstone

muddy gravel

tephra beds

sand, sand with muddy laminae

sandy limestone

muddy pebbles (intraclasts)

angular intraclasts

shell debris

angular clasts

pebbles

parallel lamination

flaser bedding

irregular lamination

Fig. 4. Subdivision of the sedimentary and palaeontological succession in the boreholes studied in lithostratigraphic logs

$$
\mathbf{A}-\mathrm{PY} 5, \mathbf{B}-\mathrm{PY} 6, \mathbf{C}-\mathrm{PY} 7
$$

\section{GEOCHEMISTRY}

Two clear clusters were distinguished in geochemical analysis (Fig. 5). One cluster shows $\delta^{13} \mathrm{C}$ from -0.1 to $-0.8 \%$ while the second one has values $\delta^{13} \mathrm{C}$ from -2.1 to $-2.9 \%$. Similarly, $\delta^{18} \mathrm{O}$ values show separation into two clusters (one from 1.6 to $1.3 \%$, the second from 0.7 to $1.1 \%$ ). These clusters do not reflect taxonomy, as all fossil groups analysed include samples belonging to both clusters. There are no differences between Cheilostomata and Cyclostomata, nor as regards the sizes of the colonies. Shift in $\delta^{13} \mathrm{C}$ recorded in the nearby section of Podbřežice (Nehyba et al., 2008) was not evident. Therefore, we assume that this sharp distinction may indicate two different original environments.

The palaeotemperature calculated from $\mathrm{O}$ isotopes ranges between 16.5 and $18.2^{\circ} \mathrm{C}$ for the first cluster and 14.4 and 


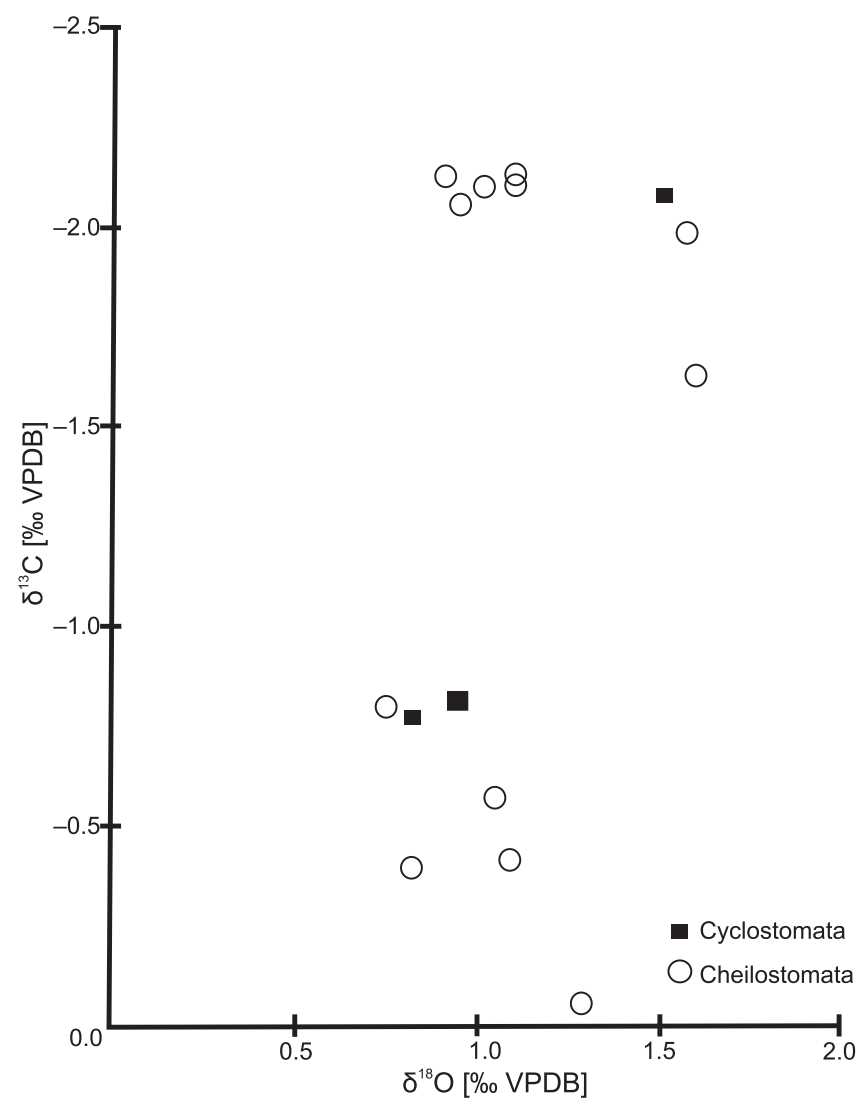

Fig. 5. Results of stable isotope analyses of bryozoan skeletons

$15.7^{\circ} \mathrm{C}$ for the second cluster. The proposed higher $\delta^{18} \mathrm{O}$ value for Badenian seawater $(+1 \%$ sMOW $)$, due to evaporation, was accepted (similarly Latal et al., 2006; cf. Peryt and Gedl, 2010) for the calculation of palaeotemperatures. The isotopic palaeotemperatures were calculated from the $\delta^{18} \mathrm{O}$ values using the equation: $T\left({ }^{\circ} \mathrm{C}\right)=16.9-4.2(\delta \mathrm{c}-\delta \mathrm{w})+0.13(\delta \mathrm{c}-\delta \mathrm{w}) 2$, where $\delta c$ denotes the $\delta^{18} \mathrm{O}$ value of the sample relative to the PDB standard and $\delta w$ denotes the $\delta^{18} \mathrm{O}$ value of seawater relative to the SMOW standard. These results are in agreement with a proposed subtropical climate for the Early to Middle Miocene of Central Europe based on ectothermic vertebrates (Böhme, 2003) and fishes (Schultz, 2003).

\section{PALAEONTOLOGY}

\section{FORAMINIFERS}

Assemblages from the boreholes studied contain the Lower Badenian index fossil - Uvigerina macrocarinata. Rarely, the Karpatian reworked species Pararotalia canui and Pappina breviformis were found. Pappina breviformis also belongs to the lowest Badenian sensu Cicha et al. (1998). Benthos dominates; planktonic species are very rare, agglutinated foraminifers were identified sporadically.
We distinguish two foraminiferal assemblages:

- Amphistegina assemblage (AA) - moderately large tests of Amphistegina mammilla and/or Elphidium div. sp. coupled with the taxa Asterigerinata planorbis and Quinqueloculina div. sp. Amphistegina is a shallow-water genus inhabiting warm waters of the inner shelf $0-130 \mathrm{~m}$ deep (winter minimum is about $15^{\circ} \mathrm{C}$, in summer over $20^{\circ} \mathrm{C}$ ), epifauna inhabiting coral reefs, lagoons, often coupled with Elphidium div. sp. - i. e. marine species of the inner shelf to $70 \mathrm{~m}$, which can inhabit brackish to hypersaline marshes and lagoons (all after Murray, 2006).

- Lenticulina assemblage (LA) - larger and smaller tests of Lenticulina div. sp., and also Heterolepa div. sp. coupled with small tests of deep-water foraminifers inhabiting colder water. Lenticulina after Murray (2006) is a marine genus, inhabiting cold water of outer shelf to bathyal depths; Pullenia bulloides, Melonis pompilioides and numerous Heterolepa dutemplei have similar characteristics.

\section{BRYOZOA}

Bryozoans occur in almost all samples studied and compose the largest part of the fossil content in washed residua (more than $80 \mathrm{wt} . \%$ of all fossils found belong to bryozoans on average). The association is very diverse, more than 100 species being determined altogether; the list of bryozoans determined is given in Appendix (supplementary file ${ }^{*}$ ).

Volumetrically dominant in the association are celleporid globular colonies, which are, however, undeterminable to genus level. Very common also are rigid erect colonies of the species Smittina cervicornis, Metrarabdotos maleckii and Crisidmonea foraminosa, followed by an association of opportunistic species such as Hornera cf. frondiculata, Onychocella angulosa, Pleuronea pertusa, Reteporella sp. and Tetrocycloecia dichotoma.

Two associations may be distinguished in the boreholes studied. The older one shows lower diversity ( $\leq 40$ species) with a dominance of cyclostomatous species (Crisidmonea foraminosa, Tervia irregularis, Exidmonea atlantica, Mecynoecia pulchella) and the upper one contains a more diverse association (about 50-60 species) dominated by cheilostomatous colonies such as Adeonella polystomella, Smittina cervicornis and Metrarabdotos maleckii.

The bryozoan association from Přemyslovice is one of the most diverse within the CF. The most similar is the assemblage from Podbřežice where 112 species were determined (Zágoršek, 2010a), and from Kralice nad Oslavou where 97 species were found (Zágoršek et al., 2009). There is no large difference in species composition with the CF bryozoans associations described previously (Zágoršek, 2010a, b), except in the presence of Poricella areolata which has not been found in any other section.

\footnotetext{
* Supplementary files are available on website: www.gq.pgi.gov.pl
} 


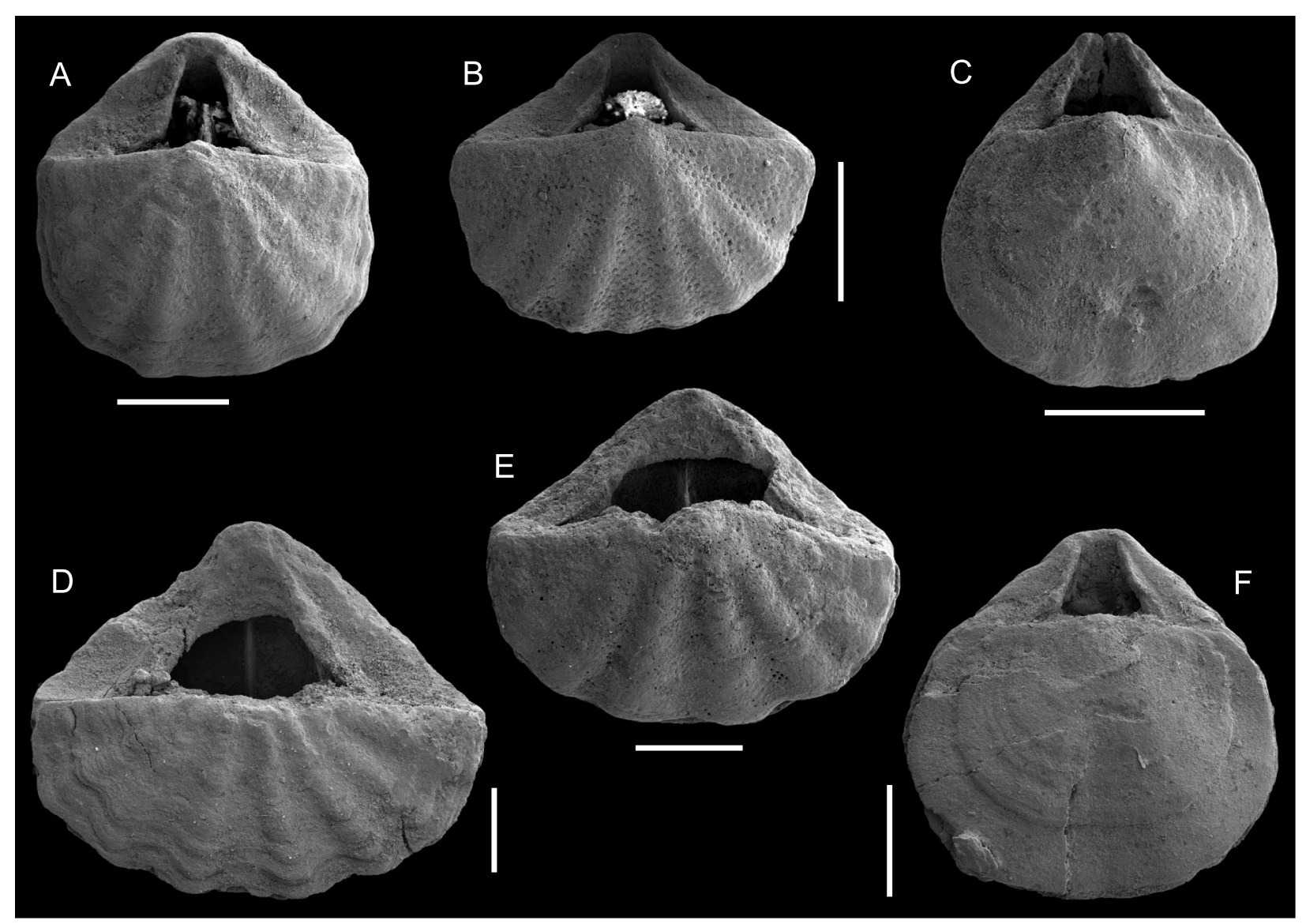

Fig. 6. Brachiopods found in Přemyslovice

A, B - Argyrotheca cuneata $; \mathbf{C ,}$ F - Joania cordata $; \mathbf{D}, \mathbf{E}$ - Megathiris detruncata, scale bar - $1 \mathrm{~mm}$

\section{BRACHIOPODA}

The investigated brachiopods from Přemyslovice are rare and of low diversity; only four species have been determined: the large, smooth terebratulide Terebratula sp. and three micromophic megathyrid species Megathiris detruncata, Argyrotheca cuneata, and Joania cordata (Fig. 6), A. cuneata dominating in the material studied.

Recent representatives of the species described here have a very wide depth range, from a few metres to more than $800 \mathrm{~m}$, thus not being good depth indicators. In shallow water the Megathyrididae occupy sheltered cryptic habitats such as caves, crevices and overlongs (Jackson et al., 1971; Logan, 1977; Richardson, 1997). The presence of a suitable substrate is considered to be one of the most important factors controlling the distribution of brachiopods. All species recognized in the samples studied have a functional pedicle opening and lived attached to a firm substrate by the pedicle.

\section{RED ALGAE}

Red algae (Rhodophyta, Corallinaceae, Sporolithaceae) are present in two boreholes (PY7 and PY6) in the depth interval 2.2 to $0.5 \mathrm{~m}$ (Table 2). They often form rhodoliths with eroded and broken surfaces, or thin crusts overgrowing bryozoans, or fragments of these two forms. Species of coralline algae present of Přemyslovice are listed in Table 2. Samples of rhodoliths and nodules were collected from different depths in the boreholes. Though many nodules were present at different depth levels, most of these were bryozoan colonies overgrown by thin crusts of coralline algae. Rhodoliths are extensively bored with Ichnoreticulina elegans, an ichnofacies of epi/endolithic green alga Ostreobium quekettii (Fig. 7). Traces of Ichnoreticulina world-wide are distributed in the shallow marine environment to depths of more than $90 \mathrm{~m}$ (Kornmann and Sahling, 1980; Chazottes et al., 2009; Aponte and Ballentine, 2001).

\section{MOLLUSCS}

All the boreholes studied are markedly dominated by bivalves (with fragments of Pectinidae and Ostreidae generally prevailing), whereas scaphopods and gastropods (Fig. 7) are much more scarce both as individuals and species (Appendix).

\section{PALYNOLOGY}

All studied samples were nearly sterile and contained almost no organic debris; only sporadic bleached and degraded palynomorphs were observed. 
Biometry of red algal taxa

\begin{tabular}{|c|c|c|c|c|c|c|c|}
\hline $\begin{array}{l}\text { Coralline algae } \\
\text { species }\end{array}$ & \multicolumn{2}{|c|}{$\begin{array}{l}\text { Borehole } \\
\text { and depth }\end{array}$} & $\begin{array}{l}\text { Hypothallium } \\
{[\mu \mathrm{m}]}\end{array}$ & $\begin{array}{l}\text { Perithallium } \\
\qquad \mu \mathrm{m}]\end{array}$ & $\begin{array}{l}\text { Types of } \\
\text { conceptacles }\end{array}$ & $\begin{array}{c}\text { Tetra/bi sporangial } \\
\text { conceptacles or sori } \\
{[\mu \mathrm{m}]}\end{array}$ & $\begin{array}{l}\text { Special } \\
\text { marks }\end{array}$ \\
\hline Lithothamnion minervae & ------- & $\begin{array}{l}\text { Py7 } \\
80 \mathrm{~m}\end{array}$ & $\begin{array}{c}\text { L } 14.25-21.36 \\
\text { H } 8.0-11.92\end{array}$ & $\begin{array}{l}\text { L } 11.19-15.35 \\
\text { D 9.19-12.13 } \\
\end{array}$ & multiporate & $\begin{array}{l}\text { H } 128-175 \\
\text { D } 258-415 \\
\end{array}$ & $\begin{array}{l}\text { triangular chambers } \\
\text { at the top of conceptacles }\end{array}$ \\
\hline Lithothamnion philippi & $\begin{array}{l}\text { Py6 } \\
50 \mathrm{~m} \\
100 \mathrm{~m}\end{array}$ & ------ & $\begin{array}{c}\text { L } 15.64-18.58 \\
\text { H 7.07-8.55 }\end{array}$ & $\begin{array}{l}\text { L } 5.53-9.89 \\
\text { D } 6.9-10.47\end{array}$ & multiporate & $\begin{array}{l}\text { H } 178.19-206.78 \\
\text { D } 579.65-679.38\end{array}$ & $\begin{array}{l}\text { type of zonation and size } \\
\text { of the conceptacles }\end{array}$ \\
\hline Lithothamnion cf. valens & $\begin{array}{l}\text { Py6 } \\
130 \mathrm{~m} \\
140 \mathrm{~m}\end{array}$ & $\begin{array}{l}\text { Py7 } \\
160 \mathrm{~m} \\
170 \mathrm{~m}\end{array}$ & $\begin{array}{l}\text { L } 11.38-19.52 \\
\text { H } 6.72-8.55\end{array}$ & $\begin{array}{l}\text { L 7.92-14.04 } \\
\text { D 7.13-8.78 }\end{array}$ & multiporate & $\begin{array}{l}\text { H } 108.63-113.33 \\
\text { D 417.21-483.23 }\end{array}$ & $\begin{array}{l}\text { zonation of perithallium } \\
\text { size of conceptacles }\end{array}$ \\
\hline Lithothamnion sp. & $\begin{array}{l}\text { Py6 } \\
100 \mathrm{~m}\end{array}$ & ------ & $\begin{array}{l}\text { L } 9.91-18.43 \\
\text { H } 5.38-8.15\end{array}$ & $\begin{array}{l}\text { L } 6.39-11.63 \\
\text { D } 5.38-6.75\end{array}$ & multiporate & $\begin{array}{l}\text { H } 201.15 \\
\text { D } 519.62\end{array}$ & $\begin{array}{l}\text { big conceptacles at the top } \\
\text { of the short perithallium }\end{array}$ \\
\hline Mesophyllum obsitum & ------ & $\begin{array}{l}\text { Py7 } \\
170 \mathrm{~m}\end{array}$ & $\begin{array}{c}\text { L } 16.22-20.19 \\
\text { H } 8.25-9.49\end{array}$ & $\begin{array}{l}\text { L } 10.2-13.26 \\
\text { D } 6.37-8.84\end{array}$ & multiporate & $\begin{array}{l}\text { H } 111.61 \\
\text { D } 273.53\end{array}$ & $\begin{array}{l}\text { perithallium without } \\
\text { zonation }\end{array}$ \\
\hline Mesophyllum sancti-dionysii & $\begin{array}{l}\text { Py6 } \\
80 \mathrm{~m} \\
100 \mathrm{~m} \\
130 \mathrm{~m} \\
140 \mathrm{~m} \\
220 \mathrm{~m} \\
\end{array}$ & ------ & $\begin{array}{c}\text { L } 13.61-16.62 \\
\text { H 5.2-8.53 }\end{array}$ & $\begin{array}{l}\text { L 7.16-13.14 } \\
\text { D 5.59-7.88 }\end{array}$ & multiporate & $\begin{array}{l}\text { H } 172.38-178.11 \\
\text { D } 339.36-429.81\end{array}$ & $\begin{array}{l}\text { size and shape of } \\
\text { conceptacles and zonation } \\
\text { of perithallium }\end{array}$ \\
\hline Mesophyllum sp. & ------ & $\begin{array}{l}\text { Py7 } \\
80 \mathrm{~m}\end{array}$ & $\begin{array}{l}\text { L } 15.78-21.63 \\
\text { H } 8-10.61\end{array}$ & $\begin{array}{l}\text { L } 12.18-17.76 \\
\text { D } 9.4-11.32\end{array}$ & multiporate & $\begin{array}{l}\text { H } 102.77 \\
\text { D } 270.71\end{array}$ & $\begin{array}{l}\text { small conceptacles } \\
\text { thalus without zonation }\end{array}$ \\
\hline Phymatolithon calcareum & $\begin{array}{l}\text { Py } 6 \\
140 \mathrm{~m} \\
\end{array}$ & $\begin{array}{l}\text { Py7 } \\
160 \mathrm{~m} \\
\end{array}$ & $\begin{array}{l}\text { L } 7.11-8.3 \\
\text { H } 3.16-3.56 \\
\end{array}$ & $\begin{array}{l}\text { L } 5.2-9.22 \\
\text { D } 3.56-6.32 \\
\end{array}$ & multiporate & $\begin{array}{c}\text { H } 106.18-116.8 \\
\text { D 206.79-214 }\end{array}$ & $\begin{array}{l}\text { discoidal chamber at } \\
\text { the top of the conceptacles }\end{array}$ \\
\hline Lithophyllum sp. & $\begin{array}{l}\text { Py6 } \\
130 \mathrm{~m}\end{array}$ & ----- & ------ & $\begin{array}{l}\text { L } 5.26-13.15 \\
\text { D } 6.57-10.52\end{array}$ & uniporate & $\begin{array}{l}\text { H } 113-134 \\
\text { D 302.5-368 }\end{array}$ & $\begin{array}{c}\text { thallus was present } \\
\text { without hypothallium, } \\
\text { no cell fusion, uniporate } \\
\text { conceptacles }\end{array}$ \\
\hline $\begin{array}{l}\text { Lithophylloideae/ } \\
\text { Mastophoroideae }\end{array}$ & $\begin{array}{l}\text { Py6 } \\
110 \mathrm{~m} \\
\end{array}$ & ------ & ------ & ------ & uniporate & $\begin{array}{l}\text { H } 199.88 \text { ph } 131.5 \\
\text { D } 515.48 \text { pd } 57.86\end{array}$ & further analyses needed \\
\hline Neogoniolithon sp. & $\begin{array}{l}\text { Py6 } \\
130 \mathrm{~m}\end{array}$ & $\begin{array}{l}\text { Py7 } \\
160 \mathrm{~m}\end{array}$ & $\begin{array}{l}\text { L } 6.57-13.15 \\
\text { H 7.89-10.52 }\end{array}$ & $\begin{array}{l}\text { L } 9.2-13.15 \\
\text { D } 5.26-7.89\end{array}$ & uniporate & $\begin{array}{l}\text { H } 105.2-131.5 \\
\text { D 315.6-410.28 }\end{array}$ & $\begin{array}{l}\text { uniporate conceptacles } \\
\text { fusion of the cells in } \\
\text { perithallium coaxial } \\
\text { hypothallium }\end{array}$ \\
\hline Sporolithon sp. & $\begin{array}{l}\text { Py6 } \\
100 \mathrm{~m} \\
\end{array}$ & ----- & $\begin{array}{c}\text { L } 12.66-15.91 \\
\text { H } 6.15-6.54 \\
\end{array}$ & $\begin{array}{l}\text { L 5.15-11.87 } \\
\text { D 5.59-8.4 } \\
\end{array}$ & sori & $\begin{array}{l}\text { H } 81.36-93.54 \\
\text { D 45.88-46.88 } \\
\end{array}$ & type of conceptacles \\
\hline
\end{tabular}



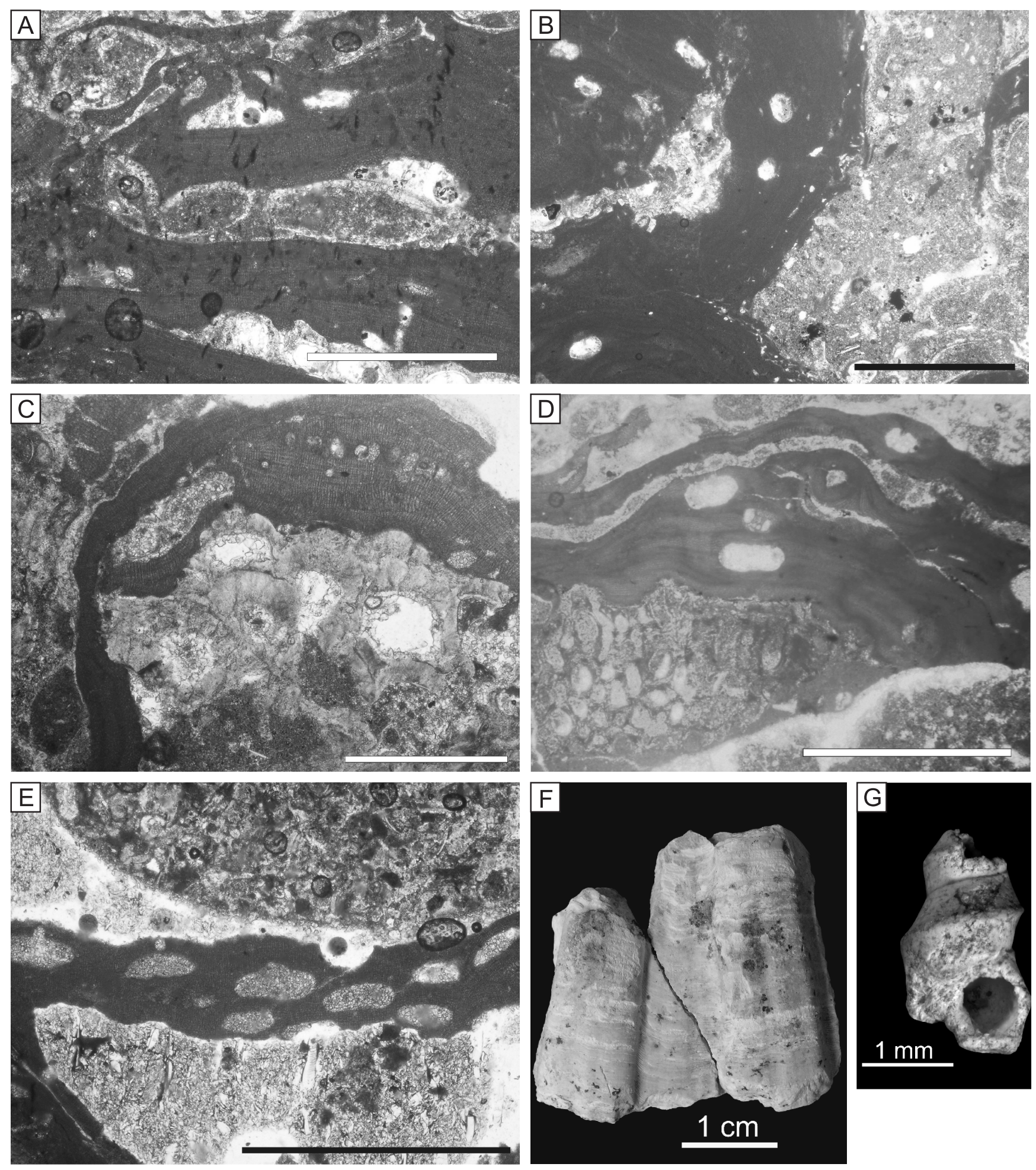

Fig. 7. Examples of algae and molluscs found in the samples studied

A - Neogoniolithon sp.; B - Phymatolithon calcareum; C - Sporolithon sp.; D - Mesophyllum sancti-dionysii; $\mathbf{E}$ - Lithophyllum sp. 1; A-D - scale bars - $1 \mathrm{~mm} ; \mathbf{F}$ - Macrochlamis sp., $\mathbf{G}$ - Turritella sp. 


\section{UNITS A-D AND \\ THEIR PALAEONTOLOGICAL CONTENT}

UNIT A

Unit A lies directly on the weathered pre-Neogene substrate. It comprises only one lithofacies, $\mathrm{Mg}$. The thickness of the unit varies between 0.6 and $1.4 \mathrm{~m}$. The deposits are poorly sorted $(\sigma \mathrm{I}=4.3)$ and a significant presence of granules and pebbles is typical (graphic mean $\mathrm{Mz}=2.5 \phi$ ). The content of psephitic material is higher towards the base of the unit where angular to subangular cobbles $(\mathrm{A} \sim 10 \mathrm{~cm})$ were recognized. The petrography of the pebbles (fraction above $4 \mathrm{~mm}$ ) indicates provenance from the direct substrate. Pebbles (spherical or bladed, rarely discoidal) of Culmian greywackes or shales strongly dominate. The pebbles are mostly subrounded or rounded, with subangular ones less common. A few percent of the pebbles is formed by milky quartz. Garnet, disthene, zoisite and apatite were recognized among the transparent heavy minerals.

The deposits are poor in macrofossils, only a few corroded, deformed and pyritised fragments being identified. Some samples contain only roundish traces resembling cysts of dinoflagellates. The lower, relatively diverse, foraminiferal assemblages consist of cold and deep-water taxa dominated by Melonis pompilioides, Heterolepa dutemplei, Hoeglundina elegans and Pullenia bulloides. Besides these, only oxidised traces of dinoflagellates and rare fragments of indetermined pectinids were found in this interval.

The upper part of the unit contains a mixed foraminifer association. Shallow and warm-water elements with a dominance of Asterigerinata planorbis, Amphistegina mammilla and Elphidium div. sp. were occurred coupled with deep, cold and euryoxibont taxa such as Melonis pompilioides, Pullenia bulloides, Heterolepa dutemplei and Lenticulina div. sp. (sensu Murray, 2006). Deep-water species (with spines) were not damaged, while specimens of Heterolepa div. sp. were usually corroded. Additional biota is limited to cyclostomatous bryozoans (Hornera, Tervia and Ceriopora), very low diversity cheilostomes (mainly Reteporella), rare molluscs (Pectinidae indet., oysters) and siliceous spicules perhaps from sponges.

\section{UNIT B}

Unit B is formed of three lithofacies ( $\mathrm{Sf}, \mathrm{Vi}, \mathrm{Vl})$, with facies $\mathrm{Vl}$ strongly dominant. The thickness of the unit varies between 0.8 and $2.3 \mathrm{~m}$. This unit can be subdivided into two subunits. Siliciclasic subunit B1 is composed of facies Sf and was recognised only in borehole (PY7) above unit A. The volcaniclastic subunit B2 was recognised in all boreholes and is formed by facies Vi and Vl. Volcaniclastic subunit lies above either unit A or subunit B1.

Deposits of siliciclastic subunit B1 are poorly sorted $(\sigma \mathrm{I}=2.9)$. The silt fraction dominates forming $56.9 \%$, with subordinate sand $(20.2 \%)$ and clay $(19.6 \%)$ (graphic mean $\mathrm{Mz}=5.9 \phi)$. A small admixture of granules and small pebbles (max. $1 \mathrm{~cm})$ was also documented. The petrography of the pebbles (fraction above $4 \mathrm{~mm}$ ) is similar to that in unit A. Pebbles (spherical or discoidal in shape) of Culmian greywackes or shales dominate. The pebbles are mostly subrounded or rounded whereas subangular ones are less common. Pebbles of milky quartz are rare whereas broken calcareous shells are frequent.

A high content of silt and very fine sand is typical of the volcaniclastic subunit B2. The content of heavy minerals is very low. Zircon, garnet and apatite dominate among transparent heavy minerals. Zircons show almost exclusively (over
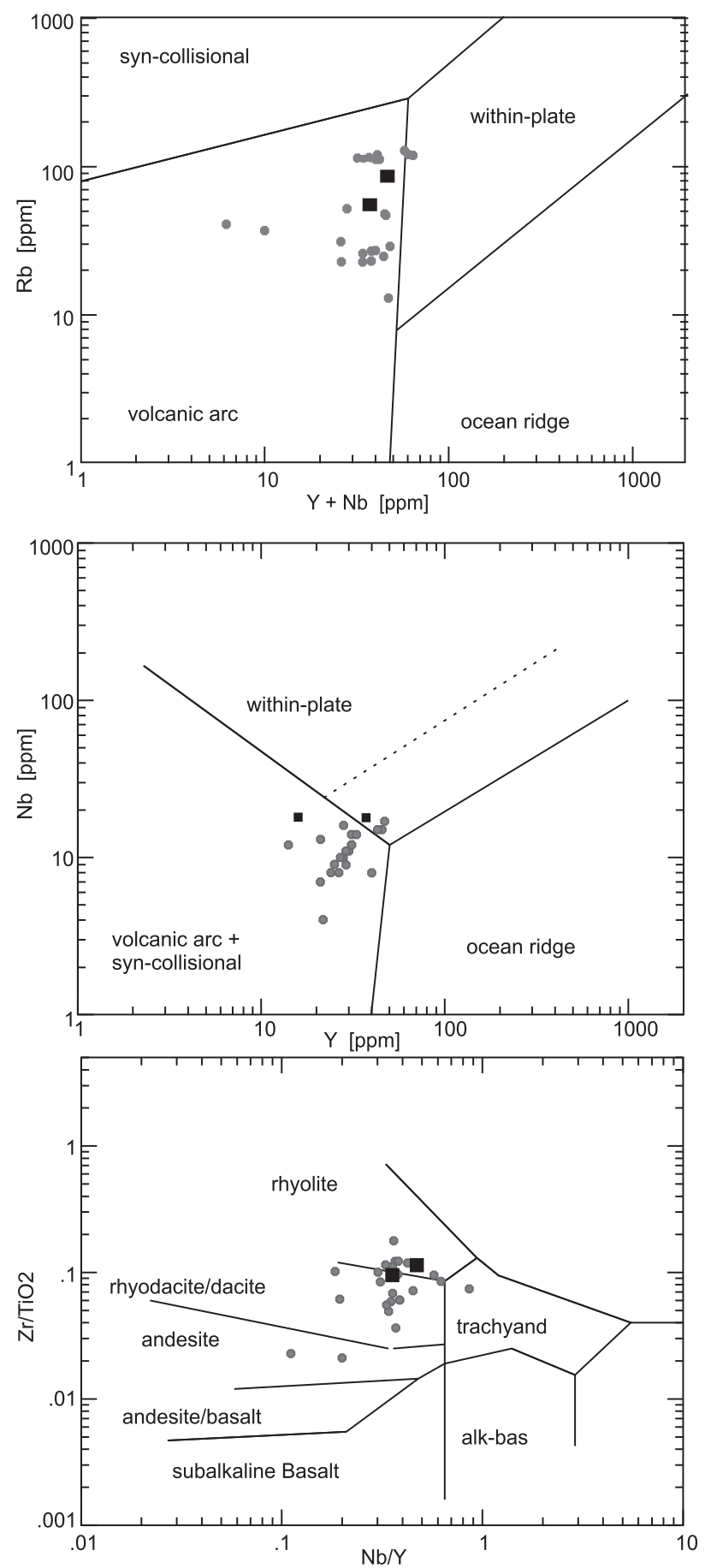

Fig. 8 Trace element discrimination diagrams for the volcaniclastic rocks clearly demonstrating that these are comparable with Early Badenian tephra known from the CF that originate from explosive eruptions of rhyolitic to rhyodacitic magmas 
90\%) an euhedral shape. Such a shape is often considered to indicate first-cycle detritus, with no previous depositional history and to be evidence of a magmatic or volcanic origin (Poldervaart, 1950; Lihou and Mange-Rajetzky, 1996). Zoned zircons with older cores were not recognized. Inclusions were observed in all zircons. Zircon typology (Pupin, 1980, 1985) was used for correlation of Neogene volcaniclastics in the CF (Nehyba, 1997; Nehyba and Roetzel, 1999; Nehyba and Stráník, 2005). Typological distribution of zircon population was based on the study of 45 grains. The majority of the zircons studied (63.6\%) comprised subtypes P1, P2, P3. Subtypes P4, S5, S8, S13, S14, S15, S18 and S22 were less common. Such zircons dominated also in volcanic zircons recognized within Early Badenian tephra beds of the basin (Nehyba, 1997). Further evidence of the volcanic provenance of zircons is the presence of crystals with a length to width ratio of more than 3 . The average elongation was 2.9 and zircons with an elongation valve over 4 form $16 \%$, and over 3 form $40 \%$, in the zircon spectra studied. These value also reflects the high role of volcanic fallout and limited redeposition of the tephra (Zimmerle, 1979). Zoned zircons with older cores were not recognized. All zircons studied show a high proportion of inclusions. A small amount of volcanic biotite was also recognized. Bulk distal tephra analyses suffer especially from postdepositional changes and for this reason they are not very suitable for tephrostratigraphy. Better results can be obtained by immobile minor and trace elements (Winchester and Floyd, 1977; Nehyba, 1997). Selected diagnostic diagrams are shown in Figure 8 and clearly demonstrate that the volcaniclastic rocks studied are comparable with other Early Badenian tephra known from the $\mathrm{CF}$ and originate from explosive eruptions of rhyolitic to rhyodacitic volcanoes (see Nehyba, 1997). This deposit can be interpreted as distal air fall tephra partly redeposited. The extent of redeposition varied between different boreholes and affected mainly the upper parts of the unit. Scattered quartz granules and chemical variations reflect the impact of redeposition. The contents of $\mathrm{Al}_{2} \mathrm{O}_{3}, \mathrm{Fe}_{2} \mathrm{O}_{3}$ and $\mathrm{CaO}$ rise whereas the contents of $\mathrm{SiO}_{2}, \mathrm{Na}_{2} \mathrm{O}$ and $\mathrm{K}_{2} \mathrm{O}$ decrease upwards in unit $\mathrm{B}$. Moreover chemical composition of the upper parts of unit B is similar to that of the basal unit A (Fig. 8).

The deposits generally contain few fossils, comprising rare fragments of foraminifers, molluscs, the brachiopod Megathiris detruncata, sponges, fragment of the alga Mesophyllum sancti-dionysii overgrowing bryozoans and dinoflagellates. All these fragments show long transport and are probably reworked.

Generally opportunistic (pioneer) community with the species Corbula gibba and Gouldia minima, optimally adapted to unstable conditions, occurs in the boreholes PY5 (2.1 m) and PY7 (4.5 m). These bivalves are typical representatives of the infauna, namely suspension or sediment feeders, shallowly burrowing in muddy bottoms of intertidal/subtidal to bathyal depths (Mandic and Harzhauser, 2003).

Several determinable pollen grains were observed in (only) this unit. Grains of Pinus, Myrica, cf. Quercus, the morphospecies Tricolporopollenites liblarensis, Chenopodiaceae and a single cyst of marine Dinophyta were found in samples from the $3.7 \mathrm{~m}$ depth in borehole PY7.
UNIT C

Unit $\mathrm{C}$ is formed of the siliciclastic lithofacies $\mathrm{Sl}, \mathrm{Hl}, \mathrm{Ms}$ and $\mathrm{Mi}$. The thickness of the unit varies between 0.3 and $0.8 \mathrm{~m}$. Although silt and very fine sand represent the dominant grain-size fraction in this unit, an admixture of small pebbles and granules was also recognized. The graphic mean Mz varies between 3.9 and $4.8 \phi$ and the sorting $\sigma \mathrm{I}$ varies between 1.7 and $2.3 \phi$. Psephitic fraction is mostly absent or its content is very low. Spherical, bladed or discoidal rounded to subrounded granules of greywacke and shale dominate, forming $50.8 \%$ of the pebbles. Broken shells are present, with angular to subangular milky quartz as a few percent. Psephitic clasts were recognized mainly at the base of the unit.

Fossil assemblages represent repeated colonizations (as in unit A) and may be divided into two associations, lower and upper one. At the boundary between these associations, a few fragments of Culmian rocks were recognized.

The lower association (subunit $\mathrm{C} 1$ ) is characterised by a richer association of plankton than benthos, a moderate diversity of bryozoans and molluscs, and siliceous sponge spicules. The foraminifers show a mixture of AA and LA assemblages with planktonic forms marginally prevalent and also the euryoxybiont genera Uvigerina and Bulimina. The small tests have well-preserved sculptures and are not damaged, while larger foraminifers are damaged with abraded surfaces. The bryozoan association started with pioneer genera (Crisidmonea, Tervia and Mecynoecia), later supplanted by cheilostomate genera (Reteporella, Celleporaria, Onychocella and Porella). Other taxa are also common; the total number of species identified varies from 44-55. Brachiopods are rare, represented by only one species, Argyrotheca cuneata. Diverse associations of molluscs are characterized by the presence of Anomia, Aequipecten cf. macrotis and Crassadoma multistriata, together with ostreids and undeterminable bivalves (mostly epibionts living on hard substrates in a shallow-water environment with strong currents). Algal remains are abundant, dominated by Lithothamnion cf. valens, Lithophyllum, Neogoniolithon sp., Mesophyllum sanctidionysii, Lithoporella sp. and Phymatolithon calcareum. Algae are present as rhodoliths or fragments of rhodoliths.

The upper association (subunit C2) is characterized by a climax association. Fossils are diverse, and the environmental conditions were ideal for rapid colonization.

The foraminifers represent a mixture of AA and LA with a slight prevalence of the latter and plankton dominanted by Amphistegina mammilla, Asterigerinata planorbis and Elphidium div. sp., rarely with Heterolepa dutemplei and Melonis pompilioides. Larger tests are abraded, without any visible sculptures on the surface. Bryozoans are very diverse, up to 60 species being determinable, dominated by cheilostomatous encrusters (Onychocella, Puellina, Umbonula) and also large erect colonies as (Smittina, Phoceana, Cellaria, Adeonella). Brachiopods are represented by Terebratula sp., Megathiris detruncata and Argytotheca cuneata; the latter species dominates. Molluscs and algae are diverse; Aequipecten macrotis, Crassadoma multistriata and Petaloconchus intortus dominate among molluscs. Common algal remains include Lithothamnion, Lithophyllum, 
Neogoniolithon, Mesophyllum and Lithoporella, a few species even forming rhodoliths (Phymatolithon). Later, rhodophytes became common (Lithothamnion philippi, L. cf. valens, L. sp., Phymatolithon calcareum, Neogoniolithon sp., Mesophyllum sancti-dionysii, M. obsitum, Lithophyllum, Sporolithon sp.) often overgrowing bryozoans or forming rhodoliths.

\section{UNIT D}

Unit D is formed of facies $\mathrm{Lg}$ and subordinate $\mathrm{Mg}$. The base of the association is sharp and erosive, with angular and subangular pebbles of Culm rocks (facies $\mathrm{Mg}$ ) recognized above it. The thickness of the association varies between $0.7 \mathrm{~m}$ and $1.55 \mathrm{~m}$. The deposits are poorly sorted with a high $\mathrm{CaCO}_{3}$ content, comprising mostly calcarenite or calcilutite with some siliciclastic content. Shell debris dominates in the psephitic fraction. Small pebbles and granules of greywackes are present, dominantly rounded to subrounded and spherical or discoidal in shape. The gravel and mud content is usually lower than in the basal facies association.

This part of the section contains the most diverse and rich foraminiferal fauna with less plankton and more abraded AA. Shallow and warm-water foraminifers such as Elphidium fichtelianum, E. crispum, Asterigerinata planorbis, Amphistegina mammilla, Quinqueloculina div. sp. predominate. Cold (deep) water species are less common than in units A and C. Among bryozoans Smittina and Metrarabdotos dominate. No large celleporids occur, only smaller ones often overgrown by red algae such as Lithothamnion sp., Mesophyllum sancti-dionysii, Mesophyllum sp., with Lithophyllum forming rhodoliths. Brachiopods contain three species, including Joania cordata not found in other units. The mollusc association is diverse; the most common fragments belong to Ostrea and Aequipecten, the presence of wood borers (Teredinidae) being notable (in boreholes PY5, PY6).

\section{DISCUSSION}

The successions studied show flooding of the irregular and weathered basement of the Bohemian Massif by the Early Badenian sea. Sedimentation started (unit A) by deposition of reworked local rocks in a relatively deepening section of the coastal area. The dinoflagellates and other fossils suggest marine conditions.

The first true marine fauna is represented by foraminifers dominated by Melonis pompilioides, Heterolepa dutemplei, Pullenia bulloides, followed later (unit A) by cyclostomatous bryozoans and molluscs. The associations as a whole are characterized by opportunistic and/or pioneer bryozoan species such as Reteporella, Tervia and Polyascosoecia, similar to the pioneer association described in the Kralice section (Zágoršek et al., 2009) and in other localities in the CF (Holcová and Zágoršek, 2008). The foraminiferal assemblage indicates deep-water conditions, unexpected during transgression. The presence of these deep-water indicators may be, however, explained by a cooler environment: a cool water current along the sea shore may have carried deeper water foraminifers to the shallow marine basin. A similar regime of inflowing of cool waters has been described from the Eocene of Slovakia (Zágoršek, 1996) and Hungary (Zágoršek, 1993).

The cool water current (an upwelling regime) may explain the faunal changes, evoking conditions resembling those of deeper water. The shallow-water fauna still flourished in areas beyond the influence of the upwelling current. The original habitats of these different faunas were close to each other, so the resulting strata include both elements of the fauna. This suggestion is consistent with the presence of two different geochemical clusters of bryozoan species as shown in Figure 5.

Inflow of the cold waters may have been connected with a steep slope towards the basin floor, are irregular coastline, strong along-coast currents and possibly also wind action. These processes may be detected indirectly by the redeposited nature of a significant part of the succession, by the thick volcaniclastic bed and the mixing of fossils from different ecological habitats. A relatively deep-water environment of the Early Badenian sea within the broader surroundings of the area under study was proposed by Brzobohatý (1997). Cold-water influx may be also supported by the dominant eastern wind direction in Central Europe during the Middle Miocene Climatic Optimum (17 and 14.5 Ma) as described by Shevenell et al. (2004) and Costeur and Legendre (2006). Such winds would have supported upwelling on eastern slopes of the basin, as on the margin of the $\mathrm{CF}$ on the Bohemian Massif, where the Přmyslovice section is situated. Similar conditions have been described from older sedimentary sequences of the Central Paratethys Sea (Grunert et al., 2010a,b).

The presence of algae from the sub-family Melobesioideae may indicate deep water with a temperate climatic belt. According to Aguirre et al. (2000) the subfamily Melobesioideae occupies deeper and/or cooler environments while the subfamilies Mastophoroideae and Lithophylloideae predominantly occur in shallow-water settings of warm and temperate climatic belts respectively. The family Sporolithaceae contains algae growing in deep-water settings in subtropical to tropical climatic belts. In this concept a predominance of Melobesioideae algae together with the low occurrence and abundance of the algal subfamilies Mastophoroideae and Lithophylloideae may indicate deeper-water settings in temperate warm climate conditions or shallow- and deep-water settings in a temperate climate belt. Rhodoliths from Přemyslovice may show a succession of environments which starts with lithophylloid and mastophoroid algae in central parts, and ends with melobesioid algae, or entire rhodoliths composed of melobesioid algae. This suggests relative deepening or cooling, of on environment occupied by algae.

However, the southern emergence of the genus Sporolithon has been located the very shallow and cool climatic conditions of Southern Island of New Zealand (Basso et al., 2009). Thus, inferences from the algal community from Přemyslovice should be correlated with those from other organisms to interpret the palaeoecology correctly.

One might also speculate about possible input of relative cooler water due to communication of the Early Badenian foreland basin towards the north with the Polish CF. 
The onset of volcanic activity sharply reduced the diversity of fossils in the sequence, with sponge spicules dominanting. Unit B represents a continuation of the transgression and relative deepening, with significant input of fallout tephra into the area studied. Redeposition of volcaniclastic material from a wider area likly played an important role, because the thickness of tephra beds here is greater compared to central/deeper parts of the basin (Nehyba, 1997). This layer of volcaniclastics may correlate into other CF sections, such as Kralice (Zágoršek et al., 2009).

The rapid redeposition of volcaniclastic material severely, and locally catastrophically affected the biota. Following the appearances of pioneer bryozoans, opportunistic molluscs and a rich association of foraminifers, the deposits contain almost no fossils at all. Volcanic material has also been described from other areas, but its fallout was not so catastrophic for the marine biota. This may be because the transgression in Přemyslovice had just started and the basin was very shallow. Therefore the volcanic material filled the basin quickly, and killed of the biota, while elsewhere the basins were deeper, the volcanic material spread over a larger area and only the benthic biota was affected. Zágoršek et al. (2008, 2009) documented an interruption in the development of the bryozoan association at Kralice, where foraminifers were little affected.

Renewed siliciclastic shallow-marine deposition is represented by unit $C$, when transgression probably reached its maximum (and so this might be regarded as a maximum flooding surface). The biota was quickly restored after termination of the input of volcanic material (subunit C1). A short period of pioneer communities was quickly replaced by a diverse assemblage of foraminifers, bryozoans and molluscs characteristic of very shallow-water. A mixture of AA and LA with a dominance of warm and shallow-water elements together with euryoxibiont taxa suggests a slight decrease in oxygen levels. Later, currents became stronger perhaps suggesting shallowing, with Culm clasts appearing within the Neogene sequence. Input of coarse material into the basin may have been connected with storms and/or relative shallowing.

The upper part (subunit C2) probably represents a new flooding cycle in a relatively shallow basin. The fossil association once more shows pioneer features, quickly replaced by typical shallow-marine assemblages within eutrophic conditions in warm (subtropical) conditions. The bryozoan association (Zágoršek, 2010b) includes fewer cool elements and indicates stronger currents. A characteristic mixture of shallowand deep-water foraminifers is interpreted as input of shallow-water elements from the shore to the deepening basin.

A changing environment reflected in red algal nodules has been widely demonstrated (Basso, 1998; Pisera and Studencki, 1989). Growth zones in rhodoliths indicate changing periods of transportation and erosion of the surface layer and periods of growth and encrustation commonly marked by microborings. Such periods of high intensity and low frequency may be regarded as reflecting storms (Bassi, 2005) or episodic currents (Lund et al., 2000). Checconi et al. (2010) described rhodoliths from the Middle Miocene of Southern Apennines, bigger but with similar abraded surfaces, as redeposited and transported basinwards from shallow to deeper settings. The small amount of algae and rhodoliths at Přemyslovice together with their mostly broken nature support this suggestion.

A reduction in siliciclastic input and deposition of sandy carbonates (red-algal limestones) is characteristic of unit D. A very shallow environment is suggested also by abundant overgrowths of bryozoans by Lithothamnion. Shallow and warm-water foraminifers such as Elphidium fichtelianum, E. crispum, Asterigerinata planorbis, Amphistegina mammilla, Quinqueloculina div. sp. predominated, cool-(deep-)water elements occurring only sporadically. Strong waters or currents may be indicated by the frequent occurrence of abraded foraminifer tests.

The scarcity and degradation of palynomorphs and organic debris most probably reflects taphonomy the boreholes studied. Pollen degradation begins with oxidation of the exine (Brooks et al., 1971). The marked degradation is a function of well-oxygenated sediments and high rates of fungal and bacterial activity. According to Hart et al. (1994) the less terrestrial organic matter is delivered to the shelf during transgression. The terrestrial organic matter deposited during transgression is reworked from below, spends more time at the sediment-water interface, and/or is exposed to more biodegradation during transport.

\section{SUMMARY}

The sedimentary succession studied near Přemyslovice shows evidence of marine flooding of the Bohemian Massif during the Early Badenian. The sedimentary profile has been subdivided into four depositional units (A-D). The basal unit A lies directly on the irregular and weathered pre-Neogene basement and represents the start of the transgression. Unit B is formed of siliciclasic subunit B1 and volcaniclastic subunit B2 and represents a further landward shift of the coastline and significant input of fallout tephra into the basin. Renewed siliciclastic shallow marine deposition is recorded in unit $\mathrm{C}$ and reduction of siliciclastic input and deposition of sandy carbonates (red-algal limestones) is characteristic of unit D.

Colonization by marine biota during transgression of the Early Badenian sea has been proposed. At first (unit A) a cool water current reached the area, but shortly after the biota was exterminated by input of volcanic material (unit B). Subsequently, the biota recovered, once more occupying the area (unit $\mathrm{C}$ ), the final association (unit D) reflected warm water conditions characteristic of the climatic optimum during this time. While other sections such as Kralice (Zágoršek et al., 2009) include volcanic material, only in the Přemyslovice area did the input cause ecological catastrophe. Nevertheless, the terminal association (unit D) is very similar to that of other sections. The biotic diversity is comparable with that of other sections such as Podbřežice, Holubice or Židlochovice (Zágoršek, 2010a,b).

Acknowledgements. The financial support of the Grant Agency of the Czech Republic (project No. TOP/08/E014, project leader J. Franců) and 205/09/0103 is gratefully acknowledged. We thank M. Harzhauser and T. M. Peryt for valuable remarks and comments in their reviews. 


\section{REFERENCES}

AGUIRRE J., RIDING R. and BRAGA J. C. (2000) - Diversity of coralline red algae: origination and extinction patterns from the Early Cretaceous to the Pleistocene. Paleobiology, 26: 651-667.

APONTE N. E. and BALLANTINE D. L. (2001) - Depth distribution of algal species on the deep insular fore reef at Lee Stocking Island, Bahamas. Deep-Sea Res., 48: 2185-2194.

BASSI D. (2005) - Larger foraminiferal and coralline algal facies in an Upper Eocene storm-influenced, shallow-water carbonate platform (Colli Berici, north-eastern Italy). Palaeogeogr. Palaeoclimatol. Palaeoecol., 226: 17-35.

BASSO D. (1998) - Deep rhodolith distribution in the Pontian Islands, Italy: a model for the paleoecology of a temperate sea. Palaeogeogr. Palaeoclimatol. Palaeoecol., 137: 173-187.

BASSO D., NALIN R. and NELSON S. C. (2009) - Shallow-water Sporolithon Rhodoliths from North Island (New Zeeland). Palaios, 24: 92-103.

BERGGREN W. A., KENT D. V., SWISHER C. C., III. and AUBRY M. P. (1995) - A revised Cenozoic geochronology and chronostratigraphy. SEPM Spec. Publ., 54: 129-212.

BÖHME M. (2003) - The Miocene climatic optimum: evidence from ectothermic vertebrates of Central Europe. Palaeogeogr. Palaeoclimatol. Palaeoecol., 195: 389-401.

BROOKS J., GRANT P. R., MUIR M., van GIJZEL P. and SHAW G. (1971) - Sporopollenin. Academic Press, London-New York.

BRZOBOHATÝ R. (1997) - Paleobathymetry of the Lower Badenian (Middle Miocene, Carpathian Foredeep, South Moravia) based on otoliths. In: Dynamika vztahů marinního a kontinentálního prostředí (ed. Š. Hladilová): 37-45. Masarykova univerzita.

BRZOBOHATÝ R. and CICHA I. (1993) - Karpatská předhlubeň (in Czech). In: Geologie Moravy a Slezska (eds. A. Přichystal, V. Obstová and M. Suk): 123-128. MZM, PřF MU.

BUBÍK M. and DVOŘÁK J. (1996) - O nálezu karpatu (miocén) a dalších výsledcích vrtu Slatinky MH-10 (in Czech). Zpr. Geol. Výzk. v r. 1995: 20-21.

CATUNEANU O. (2006) - Principles of sequence stratigraphy. Elsevier, Oxford.

CICHA I., RÖGL F., RUPP CH. and ČTYROKÁ J. (1998) Oligocene-Miocene foraminifera of the Central Paratethys. Abh. Senckenberg. Naturforsch. Ges., 549: 1-325.

CHAZOTTES V., CABIOCH G., GOLUBIC S. and RADTKE G. (2009) Bathymetric zonation of modern microborers in dead coral substrates from New Caledonia - implications for paleodepth reconstructions in Holocene corals. Palaeogeogr. Palaeoclimatol. Palaeoecol., 280: $456-468$

CHECCONI A., BASSI D., CARANNANTE G. and MONACO P. (2010) - Re-deposited rhodoliths in the Middle Miocene hemipelagic deposits of Vitulano (Southern Apennines, Italy): coralline assemblage characterization and related trace fossils. Sediment. Geol., 225: $50-66$.

COSTEUR L. and LEGENDRE S. (2006) - Mammalian communities document a latitudinal environmental gradient during the Miocene climatic optimum in Western Europe. Palaios, 23 (5): 280-288.

DOLÁKOVÁ N., BRZOBOHATÝ R., HLADILOVÁ Š. and NEHYBA S. (2008) - The red-algal facies of the Lower Badenian limestones of the Carpathian Foredeep in Moravia (Czech Republic). Geol. Carpath., 59 (2): 133-146.

FISHER R. V. and SCHMINCKE H. U. (1984) - Pyroclastic rocks. Springer, Berlin

FOLK R. L. and WARD W. (1957) - Brazos River bar: a study in the significance of grain-size parameters. J. Sediment. Petrol., 27: 3-26.

GRUNERT P., HARZHAUSER M., RÖGL F., SACHSENHOFER R., GRATZER R., SOLIMAN A. and PILLER W. E. (2010a) - Oceanographic conditions triggering the formation of an Early Miocene (Aquitanian) Konservat-Lagerstätte in the Central Paratethys Sea. Palaeogeogr. Palaeoclimatol. Palaeoecol., 292: 425-442.

GRUNERT P., SOLIMAN A., HARZHAUSER M., MÜLLEGGER S., PILLER W. E. and RÖGL F. (2010b) - Upwelling conditions in the
Early Miocene Central Paratethys Sea. Geol. Carpath., 61 (2): 129-145.

HARMS J. C., SOUTHARD J. B., SPEARING D. R. and WALKER R. G. (1975) - Depositional environments as interpreted from primary sedimentary structures and stratification sequences. SEPM Short Course, 2: $1-161$.

HART F., PASLEY M. A. and GREGORY W. A. (1994) - Particulate organic matter, maceral facies models, and application to sequence stratigraphy. In: Sedimentation of organic particles (ed. A. Traverse): 337-390. Cambridge University Press.

HOLCOVÁ K. and ZÁGORŠEK K. (2008) - Bryozoa, foraminifera and calcareous nannoplankton as environmental proxies of the "bryozoan event" in the Middle Miocene of the Central Paratethys (Czech Republic). Palaeogeogr. Palaeoclimatol. Palaeoecol., 267: 216-234.

JACKSON J. B., GOREAU T. and HARTMANN W. D. (1971) - Recent brachiopod-coralline sponge communities and their paleoecological significance. Science, 173: 623-625.

JAŠKOVÁ V. (1998) - Nově objevené miocénní locality na Prostějovsku. Přírodovědné Studie Muzea Prostějovska, 1: 133-139.

KAIHO K. (1994) - Benthic foraminiferal dissolved-oxygen index and dissolved-oxygen levels in the modern ocean. Geology, 22: 719-722.

KALABIS V. (1961) - Historie výzkumu terciéru širšího okolí Prostějova. Sborník Vlastivědného Muzea Prostějov, oddíl přírodovědný: 59-75.

KORNMAN P. and SAHLING P. H. (1980) - Ostreobium quekettii (Codiales, Chlorophyta). Helgoländer Meeresunters, 34: 115-122.

LATAL Ch., PILLER W. E. and HARZHAUSER M. (2006) - Shifts in oxygen and carbon isotope signals in marine molluscs from the Central Paratethys (Europe) around the Lower/Middle Miocene transition. Palaeogeogr. Palaeoclimatol. Palaeoecol., 231: 347-360.

LIHOU J. C. and MANGE-RAJETZKY M. A. (1996) - Provenance of the Sardona Flysch, eastern Swiss Alps: example of high-resolution heavy mineral analysis applied to an ultrastable assemblage. Sediment. Geol., 105: 141-157.

LOGAN A. (1977) - Reef dwelling articulate brachiopods from Grand Cayman. Proc. 3rd Internat. Coral Reef Symposium, Miami: 87-93.

LUND M., DAVIES P. J. and BRAGA J. C. (2000) - Coralline Algal Nodules off Fraser Island, Eastern Australia. Facies, 42: 25-34.

MANDIC O. and HARZHAUSER M. (2003) - Molluscs from the Badenian (Middle Miocene) of the Gaindorf Formation (Alpine Molasse Basin, NE Austria) - Taxonomy, Paleoecology and Biostratigraphy. Ann. Naturhistor. Mus. Wien, 104A: 85-127.

MÍSǍ̌ Z., DUDEK A., HAVLENA V. and WEISS. J. (1985) - Geologie ČSSR, Český masív (in Czech). SPN Praha.

MURRAY J. (2006) - Ecology and Applications of Benthic Foraminifera. Cambridge University Press.

NEHYBA S. (1997) - Miocene volcaniclastics of the Carpathian Foredeep in Czech Republic. Věstník Českého Geologického Ústavu, 72 (4): 311-327.

NEHYBA S. (2000) - The cyclicity of Lower Miocene deposits of the SW part of the Carpathian Foredeep as the depositional response to sediment supply and sea-level changes. Geol. Carpath., 51 (1): 7-17.

NEHYBA S. and HLADILOVÁ Ś. (2004) - Relics of the most distal part of the Neogene foreland basin in SW Moravia. Bull. Geosc., 79: $113-120$.

NEHYBA S. and ROETZEL R. (1999) - Lower Miocene volcaniclastics in Southwestern Moravia and Lower Austria. Jb. Geol. Bundesanstalt, 141 (4): 473-490.

NEHYBA S. and STRÁNÍK Z. (2005) - Vulkanoklastika v pavlovickém souvrství ždánické jednotky. Geologické výzkumy na Moravě a ve Slezsku v roce 2004, 12 (1): 37-41.

NEHYBA S., TOMANOVÁ-PETROVÁ P. and ZÁGORŠEK K. (2008) Sedimentological and palaeocological records of the evolution of the south western part of the Carpathian Foredeep (Czech Republic) during the early Badenian. Geol. Quart., 52 (1): 45-60.

NEMEC W. (2005) - Principles of lithostratigraphic logging and facies analyses. Institutt for geovitenskap, Universitat Bergen.

NOVÁK Z. (1975) - Spodnobadenské vápence karpatské předhlubně. Unpublished PhD thesis. Faculty of Science, Masaryk University Brno. 
OTAVA J., ed. (1995) - Vysvětlivky ke geologické mapě 1:50 000 list 24-21 Jevíčko. MS ČGS.

PERYT D. and GEDL P. (2010) - Palaeoenvironmental changes preceding the Middle Miocene Badenian salinity crisis in the northern Polish Carpathian Foredeep Basin (Borków Quarry) inferred from foraminifers and dinoflagellate cysts. Geol. Quart., 54 (4): 487-508.

PICHA F. J., STRÁNÍK Z. and KREJČÍ O. (2006) - Geology and hydrocarbon resources of the Outer Western Carpathians and their foreland, Czech Republic. AAPG Mem., 84: 49-175.

PISERA A. and STUDENCKI W. (1989) - Middle Miocene rhodoliths from the Korytnica basin (Southern Poland): environmenal significance and paleontology. Acta Palaeont. Pol., 34: 179-209.

POLDERVAART A. (1950) - Statistical studies of zircon as a criterion in granitization. Nature, 165: 574-575.

POWERS M. C. (1982) - Comparison chart for estimating roundness and sphericity. AGI Data Sheet, 18.

PUPIN J. P. (1980) - Zircon and Granite Petrology. Contrib. Miner. Petrol., 73: 207-220.

PUPIN J. P. (1985) - Magmatic zonic of Hercynian granitoids in France based on zircon typology. Schweiz. Miner. Petrogr. Mitt., 65: 29-56.

READING H. G., ed. (1996) - Sedimentary environments: processes, facies and stratigraphy. Blackwell Scientific Publications, Oxford.

REMEŠ M. (1933) - Dodatky ke geologické mapě okolí olomouckého a poznámky $\mathrm{k}$ některým listům sousedním. Zprávy Komitétu pro přírodovědné zkoumání Moravy, 12: 1-28.

RICHARDSON J. (1997) - Ecology of articulated brachiopods. In: Treatise on Invertebrate Paleontology (ed. R. L. Kaesler), Part H. Brachiopoda Revised, 1: 441-462. Geological Society of America and University of Kansas, Boulder, Colorado Lawrence, Kansas.

RŮŽIČKA M., ed. (1995) - Vysvětlivky ke geologické mapě 1:50 000 list 24-21 Olomouc. MS ČGS. Praha.

SCHULTZ O. (2003) - The Middle Miocene fish fauna (excl. otolithes) from Mühlbach am Manhartsberg and Grund near Hollabrunn, Lower Austria. Ann. Naturhist. Mus. Wien, 104A:185-193.

SCHWARZ R. (1946) - Př́́spěvek k poznání neogenu na listu Olomouc. Věstník Královské České Společnosti Nauk, Třída matematicko př́rodovědná, 44: 1-20.

SHEVENELL A. E., KENNETT J. P. and LEA D. W. (2004) - Middle Miocene southern ocean cooling and Antarctic cryosphere expansion. Science, 305 (5691): 1766-1770.

SPEZZAFERRI S. and ĆORIĆ S. (2001) - Ecology of Karpatian (early Miocene) foraminifers and calcareous nannoplankton from Laa an der Thaya, Lower Austria: a statistical approach. Geol. Carpath., 52 (6): 361-374.

SPEZZAFERRI S., RÖGL F., CORIC S. and HOHENEGGER J. (2004) Paleoenvironmental changes and agglutinated foraminifera across the Karpatian/Badenian (Early/Middle Miocene) boundary in the Styrian Basin (Austria, Central Paratethys). Grzybowski Found. Spec. Publ., 8: 423-459.

TUCKER M., ed. (1988) - Techniques in Sedimentology. Blackwell Science.
VYSLOUŽIL O. (1981) - Fauna spodního badenu na lokalitě Služín v karpatské předhlubní na Moravě. MS Master Thesis, MU Brno.

WALKER R. G. and JAMES N. P. (1992) - Facies models. Response to sea level changes. Geological Association Canada.

WINCHESTER J. A. and FLOYD P. A. (1977) - Geochemical discrimination of different magma series and their differentiation products using immobile elements. Chem. Geol., 20: 325-343.

ZÁGORŠEK K. (1993) - Changes in Bryozoa community in the Upper Eocene sequence of Mátyáshegy (Hungary). Oeslenytáni Viták (Discussiones Paleontologicae), 39: 91-96.

ZÁGORŠEK K. (1996) - Paleoecology of the Eocene Bryozoan Marl in the Alpine-Carpathian Region. In: Bryozoans in Space and Time (eds. D. P. Gordon et al.): 413-422. National Institute of Water and Atmospheric Research.

ZÁGORŠEK K. (2010a) - Bryozoa from the Langhian (Miocene) of the Czech Republic. Part I: Geology of the studied sections, systematic description of the orders Cyclostomata, Ctenostomata and "Anascan" Cheilostomata (Suborders Malacostega Levinsen, 1902 and Flustrina Smitt, 1868). Acta Mus. Nat. Pragae, Ser. B, Hist. Nat., 66 (1-2): 3-136.

ZÁGORŠEK K. (2010b) - Bryozoa from the Langhian (Miocene) of the Czech Republic. Part II: Systematic description of the suborder Ascophora Levinsen, 1909 and paleoecological reconstruction of the studied paleoenvironment. Acta Mus. Nat. Pragae, Ser. B, Hist. Nat., 66 (3-4): 139-255.

ZÁGORŠEK K. and HOLCOVÁ K. (2009) - The oldest Lower Badenian bryozoan event in the Carpathian Foredeep from bore-holes in Přemyslovice (PY-1 to PY-4). Př́rodovědné studie Muzea Prostějovska, 10-11: 171-182.

ZÁGORŠEK K. and VÁVRA N. (2000) - A new method for the extraction of Bryozoans from hard rocks from the Eocene of Austria. Jb. Geol. Bundesanstalt, 142 (2): 249-258.

ZÁGORŠEK K., HOLCOVÁ K. and TŘASOŇ T. (2008)- Bryozoan event from Middle Miocene (Early Badenian) lower neritic sediments from the locality Kralice nad Oslavou (Central Paratethys, Moravian part of the Carpathian Foredeep). Internat. J. Earth Sc., 97: 835-850.

ZÁGORŠEK K., HOLCOVÁ K., NEHYBA S., KROH A. and HLADILOVÁ S̆. (2009) - The invertebrate fauna of the Middle Miocene (Lower Badenian) sediments of Kralice nad Oslavou (Central Paratethys, Moravian part of the Carpathian Foredeep). Bull. Geosc., 84 (3): 465-496.

ZAPLETAL J. (2004) - Contribution to paleogeographic evolution of Lower Badenian sedimentation in central Moravia (Czech Republic). Scripta Fac. Sc. Nat. Univ. Masarykianae Brunensis, Geology, 31-32: 87-98.

ZAPLETAL J., HLADILOVÁ Š. and DOLÁKOVÁ N. (2001) - Marine sediments of the Lower Badenian marginal facies in Olomouc. Scripta Fac. Sc. Nat. Univ. Masarykianae Brunensis, Geology, 30: 75-86.

ZIMMERLE W. (1979) - Accessory Zircon from Rhyolite, Yellowstone National Park (Wyoming, U.S.A.). Z. dt. geol. Ges., 130: 361-369. 